\title{
Feed protein utilization and nitrogen emission of young and mature Kejobong goats fed different ratios of concentrate and forage
}

\author{
Farah Nabila*, Vita Restitrisnani, Retno Adiwinarti and Agung Purnomoadi \\ Faculty of Animal and Agricultural Sciences, Diponegoro University, Jl. Prof. H. Soedarto, \\ S.H., Tembalang, Semarang, Central Java, 50275, Indonesia
}

Submitted: 14 December 2020, Accepted: 01 June 2021

\begin{abstract}
This study aimed to evaluate feed protein utilization and nitrogen emission of young and mature Kejobong goats fed different concentrations of concentrate and forage. Sixteen heads of male Kejobong goats consisted of eight heads young goats ( 5 months old) and eight heads mature goats ( 9 months old) with initial body weight (BW) of $14 \pm 1.46 \mathrm{~kg}$, and $22.3 \pm 1.99 \mathrm{~kg}$, respectively were arranged in a nested design. All goats were fed with two different rations of concentrate and forage $(\mathrm{C} 30=30 \%$ concentrate: $70 \%$ forage and $\mathrm{C} 70=$ $70 \%$ concentrate: $30 \%$ forage). The data were analyzed using ANOVA procedure. This study showed that the average daily gain (ADG) did not differ $(p>0.05)$ in both ages, but it differed $(p<0.05)$ in concentrate levels. The ADG of goats fed C70 was significantly higher $(p<0.05)$ than those of goats fed C30 in both ages. The digestible crude protein (DCP) of young and mature goats was similar $(p>0.05)$, while there was a significantly difference $(p<0.05)$ between the treatments. There were no effects of different ages of goats and concentrate levels on feed conversion ratio (FCR) ( $>>0.05)$. The different ages of goats and concentrate levels affected $\mathrm{N}$ retention (g/day) and total $\mathrm{N}_{2} \mathrm{O}$ emission (g/day). It was concluded that $\mathrm{ADG}, \mathrm{DCP}$ and FCR did not differ in mature and young Kejobong goats, while young goats had less $\mathrm{N}_{2} \mathrm{O}$ emissions than mature goats. Goats fed $70 \%$ of concentrate improved their ADG, DCP, N retention (g/day) and produced less $\mathrm{N}_{2} \mathrm{O}$ emission.
\end{abstract}

Keywords: Feed efficiency; Growth production; Protein partition

*Corresponding Author: farahnbla@gmail.com 


\section{INTRODUCTION}

Kejobong goat is one of Indonesia's domestic goats selected for its black color by crossbreeding between Kacang and Ettawa goat. Local farmers still raise their goats in the traditional feeding system depending on forages containing low nutritional quality. This condition causes low productivity on Kejobong goats. Until now, there is still limited study about the potential productivity of Kejobong goats.

Therefore, it is needed to improve Kejobong goat's productivity by improving protein level in feed as the main nutrition source for growth. Increasing crude protein levels in feed improved the average daily gain of goats (Zhu et al., 2020), however over feeding of protein will result in excessive ammonia and then excreted in the urine. Some studies reported that higher crude protein intake resulted in higher nitrogen excreted in feces (Gusha et al., 2015; Rashid et al., 2016) and urine (Zhu et al., 2020). In order to make protein used efficiently in goats and improve their productivity, it is necessary to give appropriate ratios of concentrate and forage in the diet.

The addition of concentrate in feed could improve the goat's productivity. Goats fed with ad libitum concentrate resulted in greater carcass weight than those fed $2.5 \%$ of concentrate with ad libitum rice straw (Kim et al., 2014). However, giving $60 \%$ of concentrate in feed resulted in lower rumen $\mathrm{pH}$ (5.96) than $30 \%$ of concentrate (6.28) on goats (Giger-Reverdin et al., 2014). The decrease of rumen $\mathrm{pH}$ could lead to reducing the rumen microbial activity. Another side effect of feeding high concentrate level to goats $(70 \%)$ resulted in higher $\mathrm{N}$ excretion than those fed $30 \%$ concentrate (Cantalapiedra-Hijar et al., 2011). These results indicate that different concentrations of concentrate and forage may differ in protein utilization, but it has not yet been known on Kejobong goats. On the other hand, it is known that fattening young animals can promote growth as well. A previous study reported that lambs fed 14 $18 \%$ of crude protein resulted in a high average daily gain of up to $141 \mathrm{~g}$ with no significant value on $\mathrm{N}$ and $\mathrm{N}_{2} \mathrm{O}$ emissions (Prima et al., 2019).

That study did not compare with mature sheep. Besides, goats are known to have better efficiency in utilizing protein than sheep (Kearl, 1982). There is a lack of information that compares the protein utilization between young and mature goats and its nitrogen emissions. Mature goats with greater body size will consume more than young goats, so it potentially has different protein utilization depending on feed consumed.

Therefore, this study aimed to evaluate protein utilization and nitrogen emission in young and mature Kejobong black goats fed different concentrations of concentrate and forage.

\section{MATERIALS AND METHODS}

This study was conducted at the Research Farm of Meat and Dairy Production Laboratory, Department of Animal Science, Faculty of Animal and Agricultural Sciences, Diponegoro University, Semarang, Indonesia, from October 2018 to March 2019.

Sixteen heads of male Kejobong goats consisted of eight heads young goats (5 months old) and eight heads mature goats ( 9 months old) with initial body weight (BW) of $14 \pm 1.46 \mathrm{~kg}$ and $22.3 \pm 1.99 \mathrm{~kg}$, respectively were housed in individual pen. All goats were randomly grouped and fed two different rations of concentrate and forage $(\mathrm{C} 30=30 \%$ concentrate: $70 \%$ forage and $\mathrm{C} 70=70 \%$ concentrate: $30 \%$ forage). Panicum muticum as forage and concentrate that was composed of $6 \%$ cassava meal, $45 \%$ soybean meal, $42 \%$ rice bran, $6 \%$ molasses and $1 \%$ mixed mineral on DM basis were mixed and made into the pelleted ration. The diets and drinking water were given ad libitum. The nutrient composition of the experimental diets are presented in Table 1. 
The experimental period lasted for 98 days and feed intake were calculated daily. Samples of feed were analyzed for nutrient composition following the methods of AOAC (2012). Goats were weighed individually at the beginning of the experiment in the morning before feeding to know the initial body weight. The final body weight was taken at the end of the experimental period.

Average daily gain (ADG) was calculated by subtracting final body weight to initial body weight, and then it was divided by the experimental period (day). Feed conversion ratio (FCR) was calculated by dividing dry matter intake (DMI) to ADG. Protein conversion ratio (PCR) was calculated by dividing crude protein intake (CPI) to ADG. At the $13^{\text {th }}$ week of the experimental period, total daily feces and urine were separately collected for 7 days to measure the digestibility. The feces were collected and sprayed with $10 \% \quad \mathrm{H}_{2} \mathrm{SO}_{4}$, while the urine was streamed down using a filter funnel connected to a container containing $200 \mathrm{ml}$ of $10 \% \mathrm{H}_{2} \mathrm{SO}_{4}$. The feces and urine of each goat were weighed, frozen, stored and sampled for proximate analysis. Nitrous oxide $\left(\mathrm{N}_{2} \mathrm{O}\right.$ g/day) excreted in feces and urine was calculated using IPCC guidelines (IPCC 2006), where $2 \%$ of the $\mathrm{N}$ excreted in livestock manure (feces and urine) was the emission factor that was adopted to find the amount of $\mathrm{N}_{2} \mathrm{O}$ emitted.

Table 1. Ingredients and chemical composition of the diets.

\begin{tabular}{lcc}
\hline \multirow{2}{*}{ Composition } & \multicolumn{2}{c}{ Treatments (Forage: concentrate ratio) } \\
\cline { 2 - 3 } & $\mathrm{T} 1$ & $\mathrm{~T} 2$ \\
\hline Ingredients composition, \% & 70 & 30 \\
Forage & 1.8 & 4.2 \\
Cassava meal & 13.5 & 31.5 \\
Soybean meal & 12.6 & 29.4 \\
Rice bran & 1.8 & 4.2 \\
Molasses & 0.3 & 0.7 \\
Mineral mix & & \\
Chemical composition, \% & 79.1 & 71.4 \\
Dry Matter & 11.7 & 12.7 \\
Ash & 1.65 & 2.14 \\
Ether extract & 29.9 & 25.7 \\
Crude fiber & 10 & 14.7 \\
Crude Protein & 46.7 & 44.8 \\
Nitrogen free extract & 64 & 69.7 \\
Total Digestible Nutrients & & \\
\hline
\end{tabular}

The data were analyzed using analysis of variance (ANOVA) nested design based on Sastrosupadi (2000). If there were differences between the treatments, then it was analyzed by t-test.

\section{RESULT AND DISCUSSION ADG, nutrients' intake and digestibility and feed efficiency}

The data of growth performance, DMI, CPI, DDM, DCP, FCR and PCR on Kejobong goats are presented in Table 2.
The difference of age in Kejobong goats did not affect ADG, DDM and DCP (\%) ( $p>0.05)$, except for DMI and CPI $(p<0.05)$. The ADG, CPI, DDM and DCP of goats fed $C 70$ was significantly higher $(p<0.05)$ than those of goats fed C30. The different levels of concentrate resulted in the same DMI in mature goats $(p>0.05)$, however, it was significantly different from those in young goats $(p<0.05)$. There were no effects of different ages of goats and concentrate levels on FCR and PCR ( $p>0.05)$. 
Table 2. Effect of different ages and concentrate levels on growth performance, nutrient intake, digestibility and efficiency of Kejobong goats.

\begin{tabular}{|c|c|c|c|c|}
\hline & Age & C30 & C70 & Average \\
\hline \multicolumn{5}{|l|}{ Performance of goats } \\
\hline \multirow{2}{*}{ Initial live weight, $\mathrm{kg}$} & Mature & 21.6 & 23.2 & 22.4 \\
\hline & Young & 12.7 & 15.1 & 13.9 \\
\hline \multirow[t]{2}{*}{ Final live weight, kg } & Mature & 28.4 & 32.3 & $30.4^{x}$ \\
\hline & Young & $18^{a}$ & $24.6^{\mathrm{b}}$ & $21.3^{\mathrm{y}}$ \\
\hline \multirow[t]{2}{*}{ ADG, $\mathrm{g}$} & Mature & $68.6^{\mathrm{a}}$ & $93.2^{b}$ & 80.9 \\
\hline & Young & $54.2^{\mathrm{a}}$ & $97^{\mathrm{b}}$ & 75.6 \\
\hline \multicolumn{5}{|c|}{ Nutrient intake and digestibility } \\
\hline \multirow[t]{2}{*}{ DMI, g/day } & Mature & 888 & 960 & $924^{\mathrm{x}}$ \\
\hline & Young & $601^{\mathrm{a}}$ & $791^{\mathrm{b}}$ & $696^{y}$ \\
\hline \multirow[t]{2}{*}{ CPI, g/day } & Mature & $89^{\mathrm{a}}$ & $141^{\mathrm{b}}$ & $115^{\mathrm{x}}$ \\
\hline & Young & $60.3^{\mathrm{a}}$ & $116^{\mathrm{b}}$ & $88^{y}$ \\
\hline \multirow[t]{2}{*}{ DDM, \% } & Mature & $64^{\mathrm{a}}$ & $73^{b}$ & 68.5 \\
\hline & Young & $66.5^{\mathrm{a}}$ & $71.1^{b}$ & 68.8 \\
\hline \multirow[t]{2}{*}{ DDM, g/day } & Mature & $567^{\mathrm{a}}$ & $701^{\mathrm{b}}$ & $634^{x}$ \\
\hline & Young & $399^{\mathrm{a}}$ & $562^{\mathrm{b}}$ & $481^{\mathrm{y}}$ \\
\hline \multirow[t]{2}{*}{$\mathrm{DCP}, \%$} & Mature & $75.9^{\mathrm{a}}$ & $87.4^{\mathrm{b}}$ & 81.7 \\
\hline & Young & $75.9^{\mathrm{a}}$ & $86.4^{\mathrm{b}}$ & 81.2 \\
\hline \multirow[t]{2}{*}{ DCP, g/day } & Mature & $67.5^{\mathrm{a}}$ & $123^{b}$ & $95.3^{x}$ \\
\hline & Young & $45.7^{\mathrm{a}}$ & $100^{\mathrm{b}}$ & $72.9^{y}$ \\
\hline \multicolumn{5}{|l|}{ Nutrient efficiency } \\
\hline \multirow[t]{2}{*}{ FCR } & Mature & 13.2 & 10.8 & 12 \\
\hline & Young & 11.6 & 8.26 & 9.93 \\
\hline \multirow[t]{2}{*}{ PCR } & Mature & 1.32 & 1.59 & 1.46 \\
\hline & Young & 1.17 & 1.21 & 1.19 \\
\hline
\end{tabular}

${ }_{\mathrm{a}, \mathrm{b} ; \mathrm{x}, \mathrm{y}}$ Means in the same row or column with different superscripts differ $(p<0.05)$

The similar ADG between mature and young Kejobong goats was because the young goats had an accelerated growth rate, while the growth rate of mature goats started to slow down. Goats fed $\mathrm{C} 70$ had a significantly higher $(\mathrm{p}<0.05)$ ADG than goats fed $\mathrm{C} 30$ in both ages. The ADG increased with the increase of DMI (Kustantinah et al., 2017). The DMI of Kejobong in mature goats (924 g/day) was higher $(\mathrm{p}<0.05)$ than those in young goats (696 g/day). It indicated that the greater the live weight of mature goats, the greater maintenance requirements were needed. An increase in feed intake was associated with increased goat's live weight (Brand et al.,
2017). A non-significant difference in DMI in mature goats was because there was no significant difference in their final live weight. The DMI of young goats fed C70 $(791 \mathrm{~g} /$ day $)$ was higher $(\mathrm{p}<0.05)$ than those fed C30 (601 g/day). It was because C70 contained more protein, which was good for microbial growth, so it improved the degradation rate (Tadesse et al., 2016) and finally increased feed intake.

The CPI in mature goats (115 g/day) was higher than those in young goats (88 g/day), which was correlated with DMI. The higher CPI of goats fed C70 compared to those fed C30 was due to the CPI that was affected by the DMI. The different ages of 
goats did not significantly affect $(\mathrm{p}>0.05)$ DDM and DCP (\%). It was expected that Kejobong young goats had the same digestive tract ability as mature goats to digest feed. Jiao et al. (2015) stated that functional and anatomic development of rumen in goat were achieved started at 2 months. The DDM (\%) in goats fed C70 was higher $(\mathrm{p}<0.05)$ than those fed $\mathrm{C} 30$ both in mature and young Kejobong goats. Higher crude protein (CP) and lower crude fiber (CF) content in C70 (Table 1) could be attributed to the high DDM (\%). The higher DCP (\%) in goats fed C70 was due to the increased CP content of C70 (14.7 versus $10 \%$ ) that made the diet easier to digest. The increase of CP level in diet could stimulate microbial fermentation activity and microbial protein synthesis (Pirzado et al., 2016). The similar FCR and PCR were due to the same growth rate of young and mature Kejobong goats. These results indicated that the ability of young and mature goats to convert feed intake for ADG was totally the same. Thus young Kejobong goat was potentially reared using $\mathrm{C} 70$ ration to improve growth performance and shorten the rearing period.

\section{Nitrogen balance}

The data of $\mathrm{N}$ balance on Kejobong goats are shown in Table 3. Nitrogen intake in mature goats was higher $(p<0.05)$ than that in young goats. The different goats' ages did not significantly affect $(p>0.05)$ on the total excreted $\mathrm{N}$ and $\mathrm{N}$ retention percentage. The different concentrate levels significantly affected $(\mathrm{p}<0.05) \mathrm{N}$ intake and fecal nitrogen percentage, but it had a similar effect $(\mathrm{p}>0.05)$ on $\mathrm{N}$ percentage in urine.

Table 3. Effect of different ages of goats and concentrate levels in diet on $\mathrm{N}$ balance of goats.

\begin{tabular}{|c|c|c|c|c|}
\hline & Age & C30 & C70 & Average \\
\hline \multirow[t]{2}{*}{ Nitrogen intake, g/day } & Mature & $14.2^{\mathrm{a}}$ & $22.5^{\mathrm{b}}$ & $18.4^{\mathrm{x}}$ \\
\hline & Young & $9.64^{\mathrm{a}}$ & $18.6^{\mathrm{b}}$ & $14.1^{\mathrm{y}}$ \\
\hline \multicolumn{5}{|l|}{$\mathrm{N}$ excretion } \\
\hline \multirow[t]{2}{*}{ Feces, g/day } & Mature & $4.53^{\mathrm{a}}$ & $3.58^{\mathrm{b}}$ & $4.06^{x}$ \\
\hline & Young & 3.35 & 3.37 & $3.36^{\mathrm{y}}$ \\
\hline \multirow{2}{*}{ Feces, $\%$ of $\mathrm{N}$ intake } & Mature & $24.1^{\mathrm{a}}$ & $12.6^{\mathrm{b}}$ & 18.4 \\
\hline & Young & $24.1^{\mathrm{a}}$ & $13.6^{\mathrm{b}}$ & 18.8 \\
\hline \multirow[t]{2}{*}{ Urine, g/day } & Mature & $7.06^{\mathrm{a}}$ & $10.8^{\mathrm{b}}$ & $8.93^{x}$ \\
\hline & Young & $4.23^{\mathrm{a}}$ & $9.8^{\mathrm{b}}$ & $7.02^{y}$ \\
\hline \multirow[t]{2}{*}{ Urine, $\%$ of $\mathrm{N}$ intake } & Mature & 37.5 & 38.2 & 37.8 \\
\hline & Young & 30.4 & 39.4 & 34.9 \\
\hline \multirow[t]{2}{*}{ Total, g/day } & Mature & $11.6^{\mathrm{a}}$ & $14.4^{\mathrm{b}}$ & $13^{x}$ \\
\hline & Young & $7.58^{\mathrm{a}}$ & $13.2^{\mathrm{b}}$ & $10.4^{\mathrm{y}}$ \\
\hline \multirow[t]{2}{*}{ Total, $\%$ of $\mathrm{N}$ intake } & Mature & $61.5^{\mathrm{a}}$ & $50.9^{\mathrm{b}}$ & 56.2 \\
\hline & Young & $54.5^{\mathrm{a}}$ & $53^{b}$ & 53.7 \\
\hline \multirow[t]{2}{*}{$\mathrm{N}$ retention, g/day } & Mature & $5.48^{\mathrm{a}}$ & $11.1^{\mathrm{b}}$ & $8.29^{x}$ \\
\hline & Young & $4.34^{\mathrm{a}}$ & $8.72^{\mathrm{b}}$ & $6.53^{\mathrm{y}}$ \\
\hline \multirow[t]{2}{*}{$\mathrm{N}$ retention, $\%$} & Mature & $38.5^{\mathrm{a}}$ & $49.2^{\mathrm{b}}$ & 43.8 \\
\hline & Young & 45.5 & 47 & 46.3 \\
\hline
\end{tabular}

${ }_{\mathrm{a}, \mathrm{b} ; \mathrm{x}, \mathrm{y}}$ Means in the same row or column with different superscripts differ $(p<0.05)$

The percentage of $\mathrm{N}$ retention in mature goats fed C70 was higher $(\mathrm{p}<0.05)$ than that fed $\mathrm{C} 30$, while those in young goats fed C70 and C30 were similar ( $p>0.05$ ). As mention above, the different goats' ages and concentrate levels affected 
$\mathrm{N}$ intake. These results were linearly due to the higher CPI in mature goats and goats fed C70 diet. The different ages of a goat did not affect $(p>0.05)$ the percentage of $\mathrm{N}$ excreted in feces and urine. The same percent of $\mathrm{N}$ excreted in feces was due to the same amount of DCP (\%) in mature and young Kejobong goats. The same ability of rumen to degrade feed in mature and young goats may lead to the same percentage of excreted $\mathrm{N}$ in urine. The percentage of $\mathrm{N}$ in feces of goats fed C70 was lower than those fed C30. However, the different levels of concentrate did not affect the percentage of $\mathrm{N}$ in urine. The higher DCP (\%) in goats fed C70 was confirmed with a lower percentage $\mathrm{N}$ in feces.

There was no significant difference $(p>0.05)$ between mature and young Kejobong goats on $\mathrm{N}$ retention percentage. It was due to the value of DCP percentage that did not differ in both ages of goat. The different levels of concentrate affected $\mathrm{N}$ retention percentage in mature goats, but it did not affect in young goats. These results were caused by the fecal $\mathrm{N}$ excreted by mature goats fed $\mathrm{C} 70$ was less than those fed C30. On the other hand, there was no difference on the percentage of $\mathrm{N}$ in urine, thus $\mathrm{N}$ retention percentage in mature goats fed C70 was higher. Paengkoum (2011) stated that the increase of $\mathrm{N}$ intake might increase $\mathrm{N}$ retention of goats. It can be concluded that the effect of different ages of goats and concentrate levels affected $\mathrm{N}$ retention (g/day).

\section{Nitrous oxide emission}

The data of $\mathrm{N}_{2} \mathrm{O}$ emission is presented in Table 4. The different ages of goats and concentrate levels in diet affected $(\mathrm{p}<0.05)$ fecal $\mathrm{N}_{2} \mathrm{O}$, urinary $\mathrm{N}_{2} \mathrm{O}$ and total $\mathrm{N}_{2} \mathrm{O}$. Mature Kejobong goats produced higher $(\mathrm{p}<0.05)$ nitrous oxide emissions than young goats. It was caused by the $\mathrm{N}$ excreted through feces and urine of mature goats was also higher $(\mathrm{p}<0.05)$ than those of young goats (Table 3 ).

The results of nitrous oxide emissions could be explained by the total $\mathrm{N}$ excreted through feces and urine (Prima et al., 2019). The $\mathrm{N}_{2} \mathrm{O}$ emissions in feces of mature goats fed C70 (0.09 g/day) were higher $(\mathrm{p}<0.05)$ than those fed C30 (0.07 g/day), while different concentrate levels did not affect significantly $(p>0.05)$ on fecal $\mathrm{N}_{2} \mathrm{O}$ emission of young goats. Kejobong goats fed $\mathrm{C} 70$ had higher $(\mathrm{p}<0.05)$ urinary and total $\mathrm{N}_{2} \mathrm{O}$ emissions than that fed $\mathrm{C} 30$. These results were in line with the data of $\mathrm{N}$ excreted in feces and urine.

Table 4. Effect of different ages of goats and concentrate levels in diet on $\mathrm{N}_{2} \mathrm{O}$ of goats.

\begin{tabular}{lllll}
\hline & Age & C30 & C70 & Average \\
\hline Fecal $\mathrm{N}_{2} \mathrm{O}$, g/day & Mature & $0.09^{\mathrm{a}}$ & $0.07^{\mathrm{b}}$ & $0.08^{\mathrm{x}}$ \\
& Young & 0.07 & 0.07 & $0.07^{\mathrm{y}}$ \\
Urinary $\mathrm{N}_{2} \mathrm{O}$, g/day & Mature & $0.14^{\mathrm{a}}$ & $0.22^{\mathrm{b}}$ & $0.18^{\mathrm{x}}$ \\
& Young & $0.08^{\mathrm{a}}$ & $0.20^{\mathrm{b}}$ & $0.14^{\mathrm{y}}$ \\
\multirow{2}{*}{ Total $\mathrm{N}_{2} \mathrm{O}$, g/day } & Mature & $0.23^{\mathrm{a}}$ & $0.29^{\mathrm{b}}$ & $0.26^{\mathrm{x}}$ \\
& Young & $0.15^{\mathrm{a}}$ & $0.26^{\mathrm{b}}$ & $0.21^{\mathrm{y}}$ \\
\hline
\end{tabular}

$\mathrm{a}, \mathrm{b} ; \mathrm{x}, \mathrm{y}$ Means in the same row or column with different superscripts differ $(p<0.05)$

\section{CONCLUSIONS}

It was concluded that ADG, DDM and DCP (\%), FCR, N excreted through feces and urine $(\%)$ and $\mathrm{N}$ retention $(\%)$ did not differ both in mature and young Kejobong goats, while young goats produced less $\mathrm{N}_{2} \mathrm{O}$ emission than mature goats. Goats fed concentrate $70 \%$ in diets improved ADG,
DDM, DCP, $\mathrm{N}$ retention (g/day) and produced less $\mathrm{N}_{2} \mathrm{O}$ emission.

\section{REFERENCES}

AOAC. (2012). Association of Official Analytical Chemists (19th ed.).

Brand, T. S., Van Der Merwe, D. A., Swart, E., \& Hoffman, L. C. (2017). 
Comparing the effect of age and dietary energy content on feedlot performance of Boer goats. Small Ruminant Research, 157, 40-46. https://doi.org/10.1016/j.smallrumres. 2017.10.009

Cantalapiedra-Hijar, G., Yáñez-Ruiz, D. R., Newbold, C. J., \& Molina-Alcaide, E. (2011). The effect of the feed-to-buffer ratio on bacterial diversity and ruminal fermentation in single-flow continuous-culture fermenters. Journal of Dairy Science, 94(3), 1374-1384. https://doi.org/10.3168/jds.2010-3260

Giger-Reverdin, S., Rigalma, K., Desnoyers, M., Sauvant, D., \& Duvaux-Ponter, C. (2014). Effect of concentrate level on feeding behavior and rumen and blood parameters in dairy goats: Relationships between behavioral and physiological parameters and effect of betweenanimal variability. Journal of Dairy Science, 97(7), 4367-4378. https:// doi.org/10.3168/jds.2013-7383

Gusha, J., Halimani, T. E., Ngongoni, N. T., \& Ncube, S. (2015). Effect of feeding cactus-legume silages on nitrogen retention, digestibility and microbial protein synthesis in goats. Animal Feed Science and Technology, 206, 1-7. https://doi.org/10.1016/j.anifeedsci.20 15.04.017

IPCC. (2006). Emission from Livestock and Manure Management. Guidelines for National Greenhouse Gas Inventories. Forestry, 4, 10.1-10.87.

Jiao, J., Li, X., Beauchemin, K. A., Tan, Z., Tang, S., \& Zhou, C. (2015). Rumen development process in goats as affected by supplemental feeding $\mathrm{v}$. grazing: age-related anatomic development, functional achievement and microbial colonisation. British Journal of Nutrition, 113(6), 888-900. https://doi.org/10.1017/S0007114514 004413

Kearl, L. C. (1982) Nutrient Requirement of Ruminant in Developing Countries. International Fedstuffs Institute, Utah
Agriculture Experiment Stations, Utah State University, Utah.

Kim, S. W., Park, S. B., Kim, M. J., Kim, D. H., \& Yim, D.-G. (2014). Effects of different levels of concentrate in the diet on physicochemical traits of korean native black goat meats. Korean Journal for Food Science of Animal Resources, 34(4), 457-463. https://doi.org/10.5851/kosfa.2014.34 .4 .457

Kustantinah, Adiwinarti, R., Budisatria, I. G. S., Rusman, \& Indarto, E. (2017). Improved productivity of kacang goats reared by farmers using balanced rations with different sources of protein. Pakistan Journal of Nutrition, 16(9), 672-677. https://doi. org/10.3923/pjn.2017.672.677

Paengkoum, P. (2011). Utilization of concentrate supplements containing varying levels of coconut meal by Thai native Anglo-Nubian goats. Livestock Research for Rural Development, 23(2), 1-7.

Pirzado, S. A., Zakria, M., Tariq, M., M. H. Baloch, M. H., Kalhoro, D. H., Laghari, I. H., Mughal, G. A., Parveen, F., \& Lagari, R. A. (2016). Effect of different levels of protein diets on growth performance and carcass yield of pateri male goat kids. Pure and Applied Biology, 5(4), 12001206.

https://doi.org/10.19045/bspab.2016. 50144

Prima, A., Purbowati, E., Rianto, E., \& Purnomoadi, A. (2019). The effect of dietary protein levels on body weight gain, carcass production, nitrogen emission, and efficiency of productions related to emissions in thin-tailed lambs. Veterinary World, 12(1), 72-78. https://doi.org/10.14202 /vetworld.2019.72-78

Rashid, A. M., Khan, M. J., Khandoker, M. A. M. Y., Akbar, M. A., \& Alam, M. S. (2016). Feeding different levels of energy and crude protein in compound pellet and performance of Black 
Bengal goat. IOSR Journal of Agriculture and Veterinary Science, 9(5), 23-29. https://doi.org/10.9790/ 2380-0905012329

Sastrosupadi, A. (2000). Rancangan Percobaan Praktis Bidang Pertanian. Kanisiu.

Tadesse, D., Urge, M., Animut, G., \& Mekasha, Y. (2016). Growth and carcass characteristics of three Ethiopian indigenous goats fed concentrate at different supplementation levels. SpringerPlus, 5(1), 414-421. https://doi.org/10.11 86/s40064-016-2055-2
Zhu, W., Xu, W., Wei, C., Zhang, Z., Jiang, C., \& Chen, X. (2020). Effects of decreasing dietary crude protein level on growth performance, nutrient digestion, serum metabolites, and nitrogen utilization in growing goat kids (Capra. hircus). Animals, 10(1), 151-160. https://doi.org/10.3390/ani 10010151 